Review article

\title{
A PANEL ANALYSIS OF PROFITABILITY IN THE FRUIT AND VEGETABLE PROCESSING INDUSTRY IN SERBIA
}

\author{
Stojanka Dakić1, Kristina Mijic ${ }^{2}$
}

\begin{abstract}
Summary
The aim of this paper is to identify the factors that influence the profitability of selected companies within the fruit processing industry in Serbia. Profitability was measured through the accounting indicator of the rate of return on assets (ROA). Profitability of fruit and vegetable processing companies is positive but at relatively low level. In the capacity of independent variables were used the size of the enterprise, debt ratio, quick ratio, inventory, sales growth and capital turnover ratio. The analysis covers the period from 2007 to 2015 (9 years) and includes 198 observation of the companies from the fruit and vegetable processing industry in Serbia. Panel regression model was built. The results of the conducted panel analysis showed that the sales growth and capital turnover ratio showed a statistically significant impact on profitability as a measure of the success of companies in the field of fruit and vegetable processing industry. The size of the company showed a statistically significant impact on the profitability at a level of significance of $10 \%$.
\end{abstract}

Keywords: panel analysis, profitability, ROA, fruit and vegetable processing companies.

JEL: Q13, C33, M41.

\section{Introduction}

The Serbian economy has very good prerequisites for the development of agriculture and therefore for food processing industry, such as quality arable land and favorable climate. Using these prerequisites, a large number of companies have made agriculture and food processing industry to become a very important in the Serbian economy. Managers of agricultural and food processing companies must have in mind growth and development of companies and sustainable development. While the strategy of investment in agriculture and food industry is focused on emissions, food safety inputs (raw materials, packaging materials, auxiliary materials), outputs (finished

1 Stojanka Dakić, Ph.D., Teaching Assistant, University of Novi Sad, Faculty of Economics Subotica Segedinski put no. 9-11, 24000 Subotica, Republic of Serbia, E-mail: stojankad@ef.uns.ac.rs

2 Kristina Mijić, Ph.D., Assistant Professor, University of Novi Sad, Faculty of Economics Subotica Segedinski put no. 9-11, 24000 Subotica, Republic of Serbia, E-mail: mijick@ef.uns.ac.rs

EP 2018 (65) 1 (307-321) 
goods) and tangible components within technological flows, the strategy for sustainable development of the agri-food chain aims availability of finished products through activities and processes with low or zero impact on natural conditions (Dinu, 2016).

Food processing industry has very important role in ensuring food safety and reducing dependence on imports. In Serbia, there is a long tradition within the food processing industry. Food processing industry made one of the main contributions to the growth of overall industrial production (Chamber of Commerce and Industry of Serbia, 2017). Furthermore, food processing industry in Serbia is important for its contribution to overall employment, bearing in mind, that unemployment is one of the high topic problems. According to data from Chamber of Commerce and Industry of Serbia (2017), food processing industry recorded the growth of employment of 3,5\% in 2017 and engages 83.653 employees, which present 4,3\% of overall employment in Serbia.

One of the main sectors of food processing industry in Serbia is fruits and vegetable production, besides meat and milk processing industries. Serbia has extraordinary soil condition and climate, especially for fruit and vegetable production. Furthermore, Serbia is the world's third-largest producer of raspberries and is recognizable by sour cherries, apples, plums, blackberries, blueberries etc (GFA Consulting Group, 2010). Fruits are processed into juice, marmalade, and jam. Among the vegetables, potatoes (chips), tomatoes (ketchup) and pepper (Ajvar, Ljutenica) are the most processed. Beside processing into other final products, fruits and vegetables are also processed into frozen condition for future consumption. Besides natural resources, relatively low labor costs and quality domestic input of fruit and vegetable processing industry in Serbia presents good opportunities for development of this sector.

At the market, there is the dominant position of a few large fruits and vegetables processing companies such as Frikom, Aleva and Nectar Serbia. Beside these dominant companies, other fruits and vegetable processors are still organized as micro and small companies. According to the Chamber of Commerce and Industry of Serbia (2017), micro and small enterprises present 93\% of all enterprises registered as food processors. The dominance of large players in fruit and vegetable processing industry makes that only a few brands from Serbia are internationally recognized. Competition for domestic and international market between large dominant and other small fruit and vegetable processors indicate that companies have to pay attention to the profitability. Earning profit companies create resources for future internal investments or external by increasing credit rating of the company. Therefore, profitability presents the key factor for growth and development of each company.

The aim of this paper is to investigate the profitability of companies in the Republic of Serbia from the section C - Manufacturing, group 103 - Processing and preserving of fruits and vegetables (hereinafter - fruit and vegetable processing companies). First, the descriptive statistic of profitability in the period 2007-2015 will be conducted. Secondly, profitability analysis should give the answer which internal factors have a significant influence on earning power of these companies. Internal factors such as the size of the company, ability to pay the short-term obligation, indebtedness etc. can 
have a significant influence on profitability. The question of what factors determine profitability should be on of the high priority for both researchers and practitioners, including managers, investors, debt holders and policy makers (Yazdanfar, 2013).

\section{Literature Review}

Profitability is a key factor in the growth and development of each enterprise. Due to this, a large number of research papers are focused on giving an answer to the question which factors have an impact on the profitability. Research papers about profitability factors can be divided into three groups. The first group represents the investigation of external factors which influence on profitability, such as market, business and economic environment (see more: McGahan, Porter, 1997; Callado, Soares, 2014). The second group focuses on the internal factors of profitability such as the size of enterprises, indebtedness, growth, age, lagged profitability and other factors at the level of enterprises (Burja, 2011; Chandrapala and Knapkova, 2013; Margaretha and Supartika 2016, Ke and Hiong, 2016). The third group includes research papers which investigate the influence of both internal and external factors on profitability (Schiefer and Hartman, 2013; Nuševa, Mijić, Jakšić, 2017).

Since the focus of this research paper is the influence of internal factors on the profitability, the future literature review will be a point to this subject. The literature review will point to that there is no unique methodology to investigate profitability factors.

Burja (2011) investigated which internal factors have an impact on enterprise profitability of Romanian chemical industry by using linear regression model. Among the factors with a good influence on profitability were found the efficiency of inventories, debts level, financial leverage, the efficiency of capitals. The positive impacts show also, some of the ways in order to improve the performance (Burja, 2011).

Chandrapala and Knapkova (2013) used pooled and panel cross-sectional time-series techniques to investigate the impact of internal factors on the profitability of 974 enterprises in the Czech Republic during the period 2005-2008. The results show that firm size, sales growth and capital turnover have a positive impact on the return on assets. Furthermore, the results show that debt ratio and inventory have a negative influence on profitability.

Bhutta and Hassan (2013) investigated profitability factors among food sector in Pakistan in period 2002-2016 by using multivariate regression analysis. The results showed that profitability of companies in the food sector is negatively related to the size of firm-specific characteristic.

Margaretha and Supartika (2016) used a linear regression model to investigate the influence of internal firm characteristics on the profitability of 22 enterprises listed on in Indonesia Stock Exchange during the period 2007-2012. The results show while that firm size, growth, lagged profitability have a negative effect on profitability, productivity and industry affiliation have a positive impact on profitability. The variable firm age does not have a significant impact on profitability. 
Ke and Xiong (2016) used correlation analysis and regression analysis to investigate the impact capital structure on profitability of the 18 agriculture listed companies in China. The results show a negative correlation between debt ratio and profitability (see more: Ke and Xiong, 2016).

\section{Data and Methodology}

\section{Sample and Sample Selection}

The aim of this paper is to analyze profitability and explain the dependence of the performance of the fruit and vegetable processing enterprises of the various internal factors.

The original sample includes 25 enterprises from the fruit and vegetable processing companies in Serbia. In order to construct balanced panel data, our sample consists of the enterprises that operated during the whole period 2007-2015 (9 years), so the final sample consists of 22 companies and 198 observations. The data were collected from the databases of Serbian Business Registers Agency and Scoring.

\section{Explanatory and Dependent Variables}

The performance of fruit and vegetable processing companies is measured by its profitability. Profitability of the company can be measured in several ways. Return on assets (ROA - Return on Assets) and return on equity (ROE - Return on Equity) are profitability indicators which are the most represented and often used in the analysis (Wals, 2003). In this paper, ROA has a function of the dependent variable. ROA is a more appropriate indicator of company's profitability then ROE. By Vieira (2010) "the return on equity wouldn't provide a good comparison because the small and the negative equity levels of some companies would generate distorted indicators of profitability".

The explanatory variables that are the object of the analysis are internal factors specific to each enterprise - size, debt ratio, quick ratio, inventory, sale growth, capital turnover ratio.

List of variables used in panel model is given in Table 1.

Table 1. List of variables

\begin{tabular}{|c|c|c|c|c|}
\hline Variables & $\begin{array}{c}\text { Type of } \\
\text { variables }\end{array}$ & Indicator & Explanation & $\begin{array}{c}\text { Expected } \\
\text { Impact }\end{array}$ \\
\hline $\begin{array}{c}\text { Return on } \\
\text { assets } \\
\text { (ROA) }\end{array}$ & Dependent & $\begin{array}{c}\text { Indicates company's } \\
\text { ability to generate } \\
\text { earnings from its } \\
\text { assets. }\end{array}$ & $\begin{array}{c}\text { ROA = Net Income / Total } \\
\text { Assets }\end{array}$ & - \\
\hline Size & Explanatory & $\begin{array}{c}\text { Indicates the size of } \\
\text { company }\end{array}$ & $\begin{array}{c}\text { Size }=\text { Natural log of Total } \\
\text { Assets }\end{array}$ & Positive \\
\hline Debt ratio & Explanatory & $\begin{array}{c}\text { Measures the extent } \\
\text { of a company's } \\
\text { leverage. }\end{array}$ & $\begin{array}{c}\text { Debt ratio = Total debts / } \\
\text { Total Assets }\end{array}$ & Negative \\
\hline
\end{tabular}




\begin{tabular}{|c|c|c|c|c|}
\hline Variables & $\begin{array}{c}\text { Type of } \\
\text { variables }\end{array}$ & Indicator & Explanation & $\begin{array}{c}\text { Expected } \\
\text { Impact }\end{array}$ \\
\hline Quick ratio & Explanatory & $\begin{array}{c}\text { Company's short- } \\
\text { term liquidity } \\
\text { indicator }\end{array}$ & $\begin{array}{c}\text { Quick ratio }=(\text { current } \\
\text { assets }- \text { inventories }) / \\
\text { current liabilities }\end{array}$ & Positive \\
\hline Inventory & Explanatory & $\begin{array}{c}\text { Shows the portion } \\
\text { of assets tied up in } \\
\text { inventory }\end{array}$ & $\begin{array}{c}\text { Inventory }=\text { Inventory / } \\
\text { Total Assets }\end{array}$ & Negative \\
\hline Sale growth & Explanatory & $\begin{array}{c}\text { Shows increase } \\
\text { (decrease) in sales } \\
\text { between two time } \\
\text { periods. }\end{array}$ & $\begin{array}{c}\text { Sales Growth }=(\text { Current } \\
\text { Period Sales }- \text { Previous } \\
\text { Period Sales } / \text { Previous } \\
\text { Period Sales }\end{array}$ & Positive \\
\hline $\begin{array}{c}\text { Capital } \\
\text { turnover ratio }\end{array}$ & Explanatory & $\begin{array}{c}\text { Measures capital } \\
\text { intensity of firm }\end{array}$ & $\begin{array}{c}\text { Capital turnover ratio }= \\
\text { Net Fixed Assets / Sale }\end{array}$ & Negative \\
\hline
\end{tabular}

Source: Authors illustration (based on Chandrapala and Knapkova, 2013; Bhutta and Hassan, 2013; Nuševa, Mijić, Jakšić, 2017).

\section{Methodology}

The research is based on a panel of data series which implies the necessary use of the methodology in the field of analysis of panel data series. The popularity of the panel analysis is not surprising because it takes into account the time and space component.

The advantage of the panel analysis is that data that was not sufficient for analyzing the time series or for spatial analysis joined in the panel data can provide good empirical results.

In order to analyze the impact of internal factors on profitability, as a measure of the success of the fruit processing companies in Serbia, the following general model (Pooled OLS model) was used:

$y_{i t}=\alpha+\beta_{i t} x_{i t}+u_{i t}$

where $i$ is a subscript for observation $(i=1, \ldots, \mathrm{N})$ and $t$ for time $(t=1, \ldots, \mathrm{T}), y_{i t}$ represents the dependent variable, the $\alpha$ tag for the cut, $\beta$ is $\mathrm{k} \mathrm{x} 1$ parameter vector which needs to be evaluated on independent variables, $x_{i t}$ represents $1 \mathrm{x}$ k vector observations on independent variables and $u_{i t} u_{i t}$ represents the mark for a random error (Brooks, 2008).

Although it seems simplest, the Pooled OLS model has the most limitations. The Pooled OLS model can serve as a good basis for introducing the panel analysis, and from its transformation can get much more advanced models.

The model of fixed effects and the model of random effects are mostly used regression models in panel analysis.

The model of fixed effects involves taking into account the internal dimensions of the data, while the model of random effects takes into account both internal differences and differences between individual entities (Verbeek, 2008). 
A fixed-effect model is a simple linear model in which constant member changes with each observation unit, where it is constant in time, and the general form of this model is found in equation (1).

In the random effects model, the individual enterprise differences are thought to represent random variation about some average intercept for the individual in the sample. Rather than estimate a separate fixed effect for each enterprise, you estimate an overall intercept that represents this average. Implicitly, the regression function, for the sample firms, varies randomly around this average.

The variability of the individual effects is captured by a new parameter, $\sigma_{u}^{2}$. The larger this parameter is, the more variation you find in the implicit regression functions for the firms.

Once again, the model is based on equation (1). The difference is that $\alpha=\overline{\alpha_{1}}+u_{i}$ where $u_{i}$ represents random variation.

The model becomes:

$y_{i t}=\overline{\alpha_{1}}+u_{i}+\beta_{i t} x_{i t}+u_{i t}$

The new parameter, $\sigma_{u}^{2}$, is just the variance of the random effect, $\mathrm{u}_{\mathrm{i}}$.

If $\sigma_{u}^{2}=0$ then the effects are "fixed" and you can use the fixed effects estimator if the effects are indeed different across firms or the pooled estimator if they are not.

The Hausman test was used to determine which model (fixed or random effects) should be used in regression analysis. After selecting the model for the evaluation of the coefficients, a regression analysis of the panel of data sets was made. Obtained results were tested in terms of identifying potential problems that are characteristic of panel data series (heteroskedasticity, multicollinearity, stationary etc.)

By incorporating internal variables into the previous equation, we obtain a model which assesses the impact of internal factors on the profitability of the company:

$R O A_{i t}=\alpha_{i t}+\beta_{1}$ size $_{i t}+\beta_{2}$ debt_ratio $_{i t}+\beta_{3}$ quick_ratio $_{i t}+\beta_{4}$ inventory $_{i t}+$ $\beta_{5}$ sale_growth $_{i t}+\beta_{6}$ capital_turnover_ratio $_{i t}+u_{i t}$

where $i$ is a subscript for each enterprise $(\mathrm{i}=1, \ldots, 22)$ and $t$ for each year $(\mathrm{t}=1, \ldots 9)$. In accordance with the aim of the research and after a detailed analysis of the research studies of the subject area, the following hypothesis was set up:

$\mathrm{H}_{0}$ : Firm internal factors, such as size, debt ratio, quick ratio, inventory, sale growth, and capital turnover ratio of Serbian fruit and vegetable processing companies have a significant impact on profitability measured by ROA (return on assets). 


\section{Empirical Results and Discussions}

Descriptive statistics table indicates the descriptive parameters information for the study variables. In this section, descriptive statistics of the variables used in the analysis are presented to look at the nature and validity of the data. All variables are based upon accounting values and are thus determined simultaneously.

The descriptive statistics regarding the variables in the research sample are displayed in Table 2.

Table 2. Descriptive statistics

\begin{tabular}{|l|r|r|r|r|r|r|r|}
\hline & ROA & Size & Debt ratio & $\begin{array}{c}\text { Quick } \\
\text { ratio }\end{array}$ & Inventory & $\begin{array}{c}\text { Sale } \\
\text { growth }\end{array}$ & $\begin{array}{c}\text { Capital } \\
\text { turn } \\
\text { over } \\
\text { ratio }\end{array}$ \\
\hline Mean & 0.042093 & 5.857547 & 0.624252 & 1.475455 & 0.297990 & 0.215152 & 0.681499 \\
\hline Median & 0.041350 & 5.800345 & 0.665968 & 0.770000 & 0.289840 & 0.100868 & 0.423970 \\
\hline Maximum & 0.262500 & 7.143248 & 1.000000 & 11.92000 & 0.702298 & 6.872516 & 6.579362 \\
\hline Minimum & -0.640300 & 4.674236 & 0.097736 & 0.010000 & 0.000000 & -0.750331 & 0.000000 \\
\hline Std. Dev. & 0.102950 & 0.484988 & 0.243278 & 2.154358 & 0.164701 & 0.717064 & 0.840148 \\
\hline Observations & 198 & 198 & 198 & 198 & 198 & 198 & 198 \\
\hline
\end{tabular}

Source: Author's calculation.

The average profitability of fruit processing companies in Serbia is positive, but still below the referent value of $0.10(10 \%)$ - see Figure 1.

Figure 1. Average profitability (measured by ROA) of selected fruit processing companies in Serbia in the period 2007-2015.

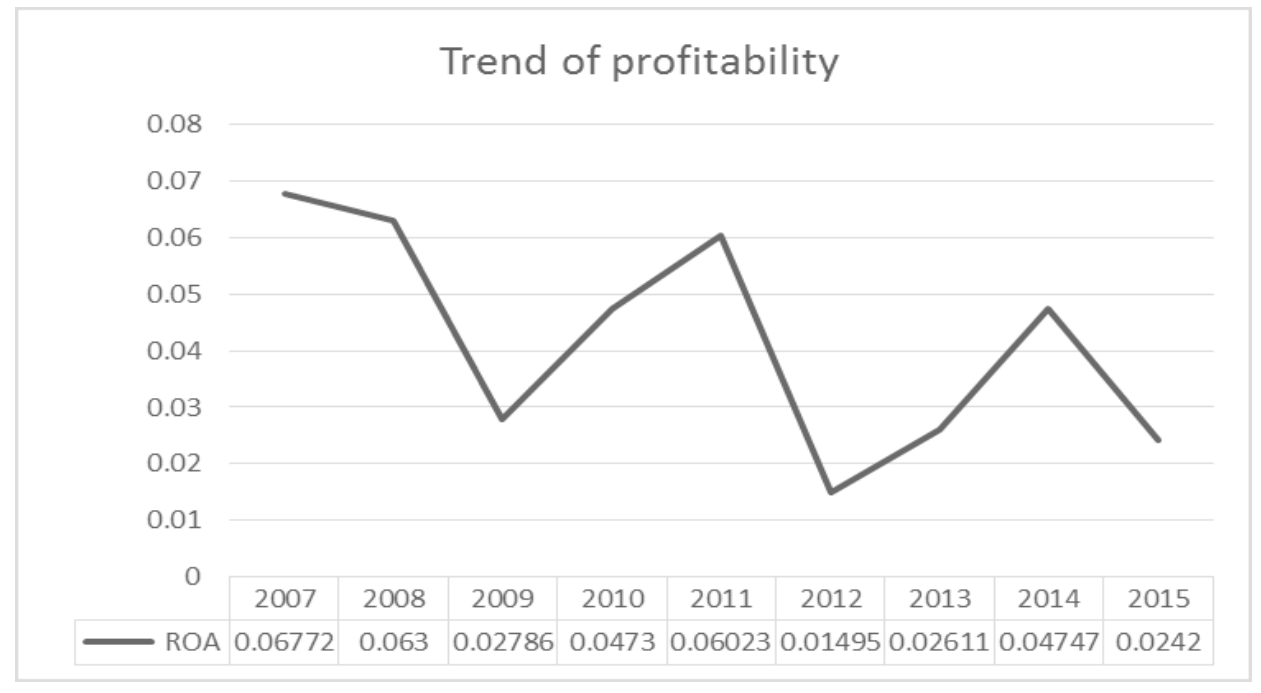

Source: Author's illustration

EP 2018 (65) 1 (307-321) 
As we can see on Figure 1, the profitability of selected fruit processing companies has characteristics of high fluctuation. In 2009 the level of profitability has fallen down to 0.02786 from the level of 0.06 in 2007 and 2008. Over the next two years (2010-2011), profitability grows slightly. If we compare the profitability in 2015 and 2007 it can be concluded that profitability level of fruit processing companies falls down for $64 \%$.

Before forming an econometric model, it is necessary to examine the correlation between the observed independent variables in order to discover the possible problem.

Multicollinearity can cause disorders in estimating the value of parameters, their significance and the direction of influence on the dependent variable.

There is no adequate test for the detection of multicollinearity in panel models. The great number of authors who used panel models in their papers, also are using coefficients of correlation between pairs of potential independent variables for perceiving the problem of multicollinearity.

Correlation among series is displayed in Table 3.

Table 3. Correlation matrix

\begin{tabular}{|l|r|r|r|r|r|r|r|}
\hline & \multicolumn{1}{|c|}{ ROA } & \multicolumn{1}{c|}{ Size } & Debt ratio & \multicolumn{1}{c|}{$\begin{array}{c}\text { Quick } \\
\text { ratio }\end{array}$} & Inventory & $\begin{array}{c}\text { Sale } \\
\text { growth }\end{array}$ & $\begin{array}{c}\text { Capital } \\
\text { turnover } \\
\text { ratio }\end{array}$ \\
\hline ROA & 1.0000 & & & & & & \\
\hline Size & -0.1680 & 1.0000 & & & & & \\
\hline Debt ratio & -0.1278 & -0.2086 & 1.0000 & & & & \\
\hline Quick ratio & 0.1332 & 0.1708 & $\mathbf{- 0 . 6 6 5 2}$ & 1.0000 & & & \\
\hline Inventory & 0.0764 & -0.0989 & $\mathbf{0 . 4 3 6 4}$ & -0.3139 & 1.0000 & & \\
\hline $\begin{array}{l}\text { Sale } \\
\text { growth }\end{array}$ & 0.1822 & -0.0153 & 0.1190 & -0.0326 & -0.0495 & 1.0000 & \\
\hline $\begin{array}{l}\text { Capital } \\
\text { turnover } \\
\text { ratio }\end{array}$ & -0.1921 & 0.1115 & -0.1897 & -0.0119 & $\mathbf{- 0 . 5 2 2 4}$ & 0.0014 & 1.0000 \\
\hline
\end{tabular}

Source: Author's calculation.

After conducting a correlation test, it can be noticed which pairs of independent variables could cause the problem of multicollinearity.

The correlation between ROA as a dependent variable and the independent variables is positive for all variables except for size, debt ratio, and capital turnover ratio. These variables are negatively correlated with return on the asset in the research sample (see Table 3).

Within the correlation matrix, we can see two strong negative correlations between quick ratio and debt ratio (-0.6652) and between capital turnover ratio and inventory $(-0.5224)$ and one medium strong positive correlation between inventory and debt ratio, which means that the simultaneous inclusion of the observed variables could lead to the problem of multicollinearity. 
Other values of correlation coefficients are not at a level that could lead to multicollinearity problems.

In order to detect multicollinearity, variance impact factors (VIF) and tolerance of variables are calculated. They are shown in Table 4.

Table 4. Variance impact factors of variables

\begin{tabular}{|c|c|c|}
\hline & Collinearit & \\
\hline & Tolerance & VIF \\
\hline Size & 0.946 & 1.057 \\
\hline Debt ratio & 0.476 & 2.100 \\
\hline Quick ratio & 0.522 & 1.917 \\
\hline Inventory & 0.587 & 1.703 \\
\hline Sale growth & 0.969 & 1.032 \\
\hline Capital turnover ratio & 0.678 & 1.475 \\
\hline
\end{tabular}

Source: Author's calculation.

In multiple regression, tolerance and the variance inflation factor (VIF) are used as indicators of multicollinearity. Acceptable level of tolerance value is 0.10 and it is recommended as the minimum level of tolerance (e.g., Tabachnick \& Fidell, 2001). The VIF recommendation of 10 corresponds to the tolerance recommendation of 0.10 . Since all VIF values are less than 10 and all tolerance values are higher than 0.10 (see Table 5), it is concluded that there is no multicollinearity between the variables.

Table 5. Results of panel unit root test

\begin{tabular}{|c|c|c|c|c|}
\hline Variables & Levin, Lin \& Chu & $\begin{array}{c}\text { Im, Pesaran and } \\
\text { Shin }\end{array}$ & $\begin{array}{c}\begin{array}{c}\text { ADF - Fisher Chi- } \\
\text { square }\end{array} \\
\end{array}$ & $\begin{array}{l}\text { PP - Fisher Chi- } \\
\text { square }\end{array}$ \\
\hline \multirow{2}{*}{ ROA } & -8.47112 & -3.74898 & 90.5362 & 103.170 \\
\hline & $(0.0000)$ & $(0.0001)$ & $(0.0000)$ & $(0.0000)$ \\
\hline \multirow{2}{*}{ Size $^{*}$} & -9.71713 & -3.78863 & 105.243 & 144.420 \\
\hline & $(0.0000)$ & 0.0001 & $(0.0000)$ & $(0.0000)$ \\
\hline \multirow{2}{*}{ Debt ratio* } & -15.8792 & -6.28362 & 128.599 & 144.806 \\
\hline & $(0.0000)$ & $(0.0000)$ & \begin{tabular}{l|l}
$(0.0000)$ \\
\end{tabular} & $(0.0000)$ \\
\hline \multirow{2}{*}{ Quick ratio } & -5.97991 & -1.74465 & 67.0305 & 82.5625 \\
\hline & $(0.0000)$ & $(0.0405)$ & $(0.0142)$ & $(0.0004)$ \\
\hline \multirow{2}{*}{ Inventory } & -9.00824 & -5.05781 & 113.783 & 119.406 \\
\hline & $(0.0000)$ & $(0.0000)$ & $(0.0000)$ & $(0.0000)$ \\
\hline \multirow{2}{*}{ Sale growth } & -20.2542 & -6.42689 & 121.212 & 86.2699 \\
\hline & $(0.0000)$ & $(0.0000)$ & $(0.0000)$ & 0.0001 \\
\hline \multirow{2}{*}{$\begin{array}{l}\text { Capital turnover } \\
\text { ratio }\end{array}$} & -31.0010 & -7.20104 & 106.837 & 110.413 \\
\hline & $(0.0000)$ & $(0.0000)$ & $(0.0000)$ & $(0.0000)$ \\
\hline
\end{tabular}

Source: Author's calculation.

Note:

- probabilities for Fisher tests are computed using an asymptotic Chi-square distribution. All other tests assume asymptotic normality.

- p-values are shown in brackets and t-statistics in normal characters above.

- * after taking the first difference. 
Common (Levin- Lin-Chu) and Individual (Im- Pesaran-Shin, ADF - Fisher Chisquare) Unit Root Tests are performed, in order to ensure stationarity of variables in the sample. The results of panel unit root tests are illustrated in Table 5. There is no significant difference between the tests.

As we can see in Table 5, the probability value for Levin, Lin \& Chu method is less than $5 \%$, so we can reject the null hypothesis and accept the alternative hypothesis meaning that our ROA and all other variables do not have unit root at level.

The same conclusion is for testing the null hypothesis by Im, Pesaran and Shin methods, as for ADF and PP Fisher Chi-square method. They all show that ROA and the others variables included in the sample does not have unit root at level.

\section{Choosing a model}

When conducting empirical research, the issue of suitability of a particular model is frequently raised. In other words, is it better to use a fixed-effect model or randommodel model?

The selection of appropriate model between the pooled OLS and the fixed effect is based on the joint significance of differing group means $(p=0.0000)$. A low $p$-value means that fixed effects model is more appropriate than the pooled OLS model (Table 6). Breusch-Pagan test statistic also showed that random effects model is adequate, rather than the pooled OLS model $(\mathrm{p}=0.0000)$. The Breusch-Pagan test is used for testing the null hypothesis: Variance of the unit-specific error $=0 \quad\left(\sigma_{u}^{2}=0\right)$ against the alternative: Variance of the unit-specific error $>0\left(\sigma_{u}^{2}>0\right)$. The p-value is less than $5 \%$ which means that the Breusch-Pagan test rejects the null hypothesis that the effects are not random and accept the alternative that the effects are random.

The selection of appropriate model between random effect and the fixed effect is based on the Hausman test The Hausman test result indicates the use of random effect model ( $p=0.541979$ is greater than 0.05 ). The random effects do not appear to be correlated with the regressors and random effects can be used.

Table 6. Panel model diagnostic (assuming a balanced panel with 22 cross-sectional units observed over 9 periods)

\begin{tabular}{|l|r|r|l|l|}
\hline Diagnostics & $\begin{array}{r}\text { Asymptotic test } \\
\text { statistic }\end{array}$ & p-value & \multicolumn{1}{c|}{$\begin{array}{c}\text { Null } \\
\text { hypothesis }\end{array}$} & \multicolumn{1}{c|}{ Decision } \\
\hline $\begin{array}{l}\text { Joint significance } \\
\text { of differing group } \\
\text { means: }\end{array}$ & $\begin{array}{r}\mathrm{F}(21,170)= \\
5.70473\end{array}$ & 0.0000 & $\begin{array}{l}\text { A low p-value counts } \\
\text { against the null hypothesis } \\
\text { that the pooled OLS } \\
\text { OLS model is } \\
\text { adequate } \\
\text { modelis adequate, in } \\
\text { favor of the fixed effects } \\
\text { alternative. }\end{array}$ \\
\hline
\end{tabular}




\begin{tabular}{|l|r|r|l|l|}
\hline $\begin{array}{l}\text { Breusch-Pagan test } \\
\text { statistic }\end{array}$ & $\mathrm{LM}=83.5794$ & $\begin{array}{r}\text { prob(chi- } \\
\text { square(1) }> \\
83.5794)= \\
0.0000\end{array}$ & $\begin{array}{l}\text { The pooled } \\
\text { OLS model is } \\
\text { adequate }\end{array}$ & $\begin{array}{l}\text { A low } \text {-value counts } \\
\text { against the null hypothesis } \\
\text { that the pooled OLS model } \\
\text { is adequate, in favor of the } \\
\text { random effects alternative. }\end{array}$ \\
\hline Hausman test & $\mathrm{H}=5.01431$ & $\begin{array}{r}\text { prob(chi- } \\
\text { square(6) }> \\
5.01431)= \\
0.541979\end{array}$ & $\begin{array}{l}\text { the random } \\
\text { effects model is } \\
\text { statistic }\end{array}$ & $\begin{array}{l}\text { p value is higher than 5\%, } \\
\text { so the null hypothesis is } \\
\text { accepted }\end{array}$ \\
\hline
\end{tabular}

Source: Author's calculation.

After providing all assumptions, the random model is performed. The coefficients estimations are given in Table 7.

Table 7. Random-effects (GLS) model

\begin{tabular}{|l|r|r|r|r|}
\hline Dependent variable & \multicolumn{4}{|c|}{ ROA } \\
\hline Variable & \multicolumn{1}{|c|}{ Coefficient } & Std. Error & \multicolumn{1}{c|}{ t-ratio } & \multicolumn{1}{c|}{ p-value } \\
\hline Const & 0.316223 & 0.145195 & 2.1779 & 0.03064 \\
\hline Size & -0.0405865 & 0.0232301 & -1.7472 & $0.08222^{* *}$ \\
\hline Debt ratio & -0.0749109 & 0.0515944 & -1.4519 & 0.14816 \\
\hline Quick ratio & 0.00635083 & 0.00459743 & 1.3814 & 0.16877 \\
\hline Inventory & 0.0381857 & 0.063136 & 0.6048 & 0.54602 \\
\hline Sale growth & 0.0360337 & 0.00836064 & 4.3099 & $0.00003^{*}$ \\
\hline Capital turnover ratio & -0.0266062 & 0.0102106 & -2.6057 & $0.00989^{*}$ \\
\hline Mean dependent var & 0.042093 & S.D. dependent var & 0.102950 \\
\hline Sum squared resid & 1.801394 & S.E. of regression & 0.096862 \\
\hline Log-likelihood & 184.3211 & Akaike criterion & -354.6422 \\
\hline Schwarz criterion & -331.6243 & \multicolumn{4}{|c|}{ Hannan-Quinn } & -345.3253 \\
\hline
\end{tabular}

Source: Author's calculation.

Note:

- $\quad$ * level of significance $5 \%$

- $\quad * *$ level of significance $10 \%$

Based on the results of the panel analysis (see Table 7), it can be concluded that the variables sales growth and capital turnover ratio are statistically significant at the level of significance of $99 \%$, while the variable size is statistically significant at the level of significance of $90 \%$. Furthermore, from the presented results it can be concluded that the variable sale growth $(0.0360337)$ has a positive influence on the ROA, while the variable size $(-0.0405865)$ and capital turnover ratio $(-0.0266062)$ have a negative influence. Other variables have not a statistically significant impact on the dependent variable. That means that the null hypothesis was partially accepted. 


\section{Conclusions}

Fruit and vegetable processing companies in the Republic of Serbia have many opportunities for developing good business, such as quality domestic fruit and vegetable as input, relatively low labor costs, a long tradition in food processing, the constant demand for food etc. Serbia is a relatively large market with more than 7 million inhabitants (Statistical Office of the Republic of Serbia, 2017). Besides the possibility for the companies to sell products on the domestic market, fruit and vegetable processing companies have great export opportunities (eg. Free trade agreement with Russia, customs-free access to EU market-CEFTA). On the other side, Serbian companies are faced with the problem low purchasing power of domestic consumers, which indicate that fruit and vegetables participate with only $9,5 \%$ of the trade turnover of food products (Statistical Office of the Republic of Serbia, 2016).

The results of the investigation the profitability of fruit and vegetable processing companies in the period 2007-2015 indicate two problems. Firstly, during this period average profitability is constantly above the reference value of 0.10 . Secondly, profitability has a generally downward trend in the period 2007-2015. If we compare the profitability in 2015 and 2007 it can be concluded that profitability level of fruit and vegetable processing companies decreased by $64 \%$. Besides these, fruit and vegetable processing companies in the Republic of Serbia have one more red flags in business and that is indebtedness. The average debt ratio of 0.62 indicates that fruit and vegetable processing companies finance business activities with $62 \%$ from borrowed funds and $38 \%$ from the capital. Traditionally, debt ratio should be 0.5 and some fruit and vegetable processing companies have debt ratio 1.0 which means that all business activities are financed from the borrowed funds. Negative relations between debt ratio and profitability indicate that additional borrowing is primarily using for servicing existing liabilities. Furthermore, the results of quick ratio test indicate that fruit and vegetable processing industry do not have problem of paying short-term liabilities. The average quick ratio of 1.47 is higher than referent value of 1.0 and shows that fruit and vegetable companies have more financially secure in the short-term.

The results of research which internal factors have an influence on the profitability of fruit and vegetable processing companies in the Republic of Serbia show the following factors as significant: size of company, sale growth and capital turnover. Size of company is negatively related to the profitability. Large companies earn more profit in absolute amount, but on the other side higher cost of interest, exchange loss etc. are reducing the profitability rate. Fruit and vegetable processing companies are increasing profitability by achieving growth in sales. Increasing sale growth has a positive significant impact on the profitability of fruit and vegetable processing companies in the Republic of Serbia. Capital turnover has a negative significant impact on profitability. This is expected, because the lower value of the capital turnover ratio may imply greater efficiency in capital utilization, which will result in higher profitability of companies.

The results of this research will enable management, owners, and potential investors to better understand the factors that influence the success of the company's business, based in which they will be able to analyze the advantages and disadvantages of 
investments in fruit processing enterprises in Serbia. Also, more information about the impact of some internal factors on profitability will enable investors' easier choice of the company they need to invest in and which will, with greater certainty, allow them to return to invested funds.

\section{Literature}

1. Adkins, L. (2014). Using gretl for Principles of Econometrics, 4th Edition Version 1.0411. Oklahoma State University, Oklahoma, USA.

2. Bhutta, N., T. and Hasan, A. (2013). Impact of Firm Specific Factors on Profitability of Firms in Food Sector, Open Journal of Accounting, vol. 2, n. 2, p. 19-25, Scientific Research Publishing Inc., Delaware, USA.

3. Brooks, C. (2008). Introductory econometrics for finance, Cambridge University Press, New York, USA.

4. Burja, C. (2011). Factors influencing the companies' profitability. Annals Universitatis Apulensis Series Oeconomica, vol. 13, n. 2, p. 215-224, "1 Decembrie 1918" University of Alba Iulia, Romania.

5. Callado, A. L. C. and Soares, K. R. (2014). Analysis of the use of performance indicators in the context of agribusiness. Custos e @gronegocio on line, vol. 10, n. 2., p. 272-284, Universidade Federal Rural de Pernambuco, Brazil.

6. Chamber of Commerce and Industry of Serbia. (2017). Bilten-Udruženje za prehrambenu industriju, Chamber of Commerce and Industry of Serbia, Belgrade, Serbia

7. Chandrapala, P. and Knapkova, A. (2013). Firm-specific factors and financial performance of firms in the Czech Republic. Acta Universitatis Agriculturae et Silviculturae Mendelianae Brunensis, vol. 61, n. 7, p. 2183-2190, Mendel University Press, Brno, Czech Republic.

8. Dinu, M, D. (2016). Supply Chain Performance within Agri Food Sector. Economics of Agriculture, vol. 63, n. 3, p. 919-928. Institute of Agricultural Economics, Belgrade, Serbia.

9. GFA Consulting Group. (2010). Food Industry Study in Southeast Europe - Final Report. GFA Consulting Group, Hamburg, Germany.

10. Ke, J. and Xiong, Y. (2016). An Empirical Study on Profitability and Capital Structure of the Agriculture Listed Companies. International Journal of Database Theory and Application, vol. 9, n. 4, p. 89-96, SERSC, Australia.

11. Levin, A., Lin, C. F. and Chu, J. (2002). Unit root in panel data: Asymptotic and finitesample Properties. Journal of Econometrics, vol. 108, n. 1, p. 1-24, Elsevire, USA

12. Maddala, G. S. and Wu, S. (1999). Comparative Study of Unit Root Tests with Panel Data and a New Simple Test. Oxford Bulletin of Economics and Statistics, n. 61, p. 631-652, John Wiley \& Sons Ltd and the Department of Economics, University of Oxford, United Kingdom.

13. Margaretha, F. and Supartika, N. (2016). Factors Affecting Profitability of Small 
Medium Enterprises (SMEs) Firm Listed in Indonesia Stock Exchange. Journal of Economics, Business and Management, vol. 4, n. 2, p. 132-137, JOEBM, USA.

14. Mcgahan, A. and Porter, M.E. (1997). How much does industry matter, really? Strategic Management Journal, vol. 18, n. 1, p. 15-30, Wiley, Medford, USA.

15. Nuševa, D., Mijić, K., Jakšić, D. (2017). The Performances of Coffee Processors and Coffee Market in the Republic of Serbia. Economics of Agriculture, vol. 64, n. 1, p. 307-322, Institute of Agricultural Economics, Belgrade, Serbia.

16. Schiefer, J. and Hartman, M. (2013). Industry, firm, year and country effects on profitability in EU food processing. Agricultural and Resource Economics Discussion Paper. University of Bonn: Institute for Food and Resource Economics, Bonn, Germany.

17. Statistical Office of the Republic of Serbia. (2016). Statistical Yearbook. Statistical Office of the Republic of Serbia, Belgrade, Serbia.

18. Statistical Office of the Republic of Serbia. (2017). Population. Retrieved October $6^{\text {th }}$ 2017, from http://webrzs.stat.gov.rs/WebSite/Public/PageView. aspx?pKey $=162$

19. Tabachnick, B. G., and Fidell, L. S. (2001). Using Multivariate Statistics (4th ed.). Allyn and Bacon, Boston, MA, USA.

20. Verbeek, M. (2008). A Guide to Modern Econometrics. John Wiley \& Sons, New York, USA.

21. Vieira, R. S. (2010). The relationship between liquidity and profitability: An exploratory study of airline companies between 2005 and 2008. Umeå University, Master Thesis, Sweden.

22. Walsh, C. (2003). Key Management Ratios. Prentice Hall, London, United Kingdom.

23. Yazdanfar, D. (2013). Profitability determinants among micro firms: evidence from Swedish data. International Journal of Managerial Finance, vol. 9, n. 2, p. 150-161, Emerald, United Kingdom. 


\title{
PANEL ANALIZA PROFITABILNOSTI U INDUSTRIJI PRERADE VOĆA I POVRĆA U SRBIJI
}

\author{
Stojanka Dakić3, Kristina Mijic ${ }^{4}$
}

\begin{abstract}
Sažetak
Cilj ovog rada je da identifikuje faktore koji utiču na profitabilnost odabranih kompanija u okviru sektora za preradu voća i povrća u Srbiji. Profitabilnost je merena preko analitičkog pokazatelja stope povrata imovine (ROA). Analiza profitabilnosti ukazuje na pozitivnu, ali relativno nisku profitabilnost. Grupu nezavisnih varijabli čine veličina preduzeća, koeficijent zaduženosti, tekuća likvidnost, koeficijent zaliha, rast prodaje i koeficijent obrta kapitala. Analizom je obuhvaćen period od 2007. do 2015. godine (9 godina) i uključuje podatke iz 198 opservacija u okviru industrije za preradu voća i povrća u Srbiji. Panel regresioni model je izgrađen. Rezultati sprovedene panel analize pokazali su da su rast prodaje i koeficijent obrta kapitala ispoljili statistički značajan uticaj na profitabilnost kao meru uspešnosti preduzé́a iz oblasti industrije za preradu voća. Veličina preduzeća je ispoljila statistički značajan uticaj na profitabilnost preduzeća pri nivou signifikantnosti od 10\%.
\end{abstract}

Ključne reči: panel analiza, profitabilnost, stopa povrata imovine, preduzeća za preradu voća i povrća.

3 Dr Stojanka Dakić, Asistent, Univerzitet u Novom Sadu, Ekonomski fakultet u Subotici Segedinski put 9-11, 24000 Subotica, Republika Srbija, E-mail: stojankad@ef.uns.ac.rs

4 Dr Kristina Mijić, Docent, Univerzitet u Novom Sadu, Ekonomski fakultet u Subotici Segedinski put 9-11, 24000 Subotica, Republika Srbija, E-mail: mijick@,ef.uns.ac.rs

EP 2018 (65) 1 (307-321) 